\title{
Fiber sources in diets for newly weaned piglets ${ }^{1}$
}

\section{Leonardo Augusto Fonseca Pascoal ${ }^{2}$, Maria Cristina Thomaz ${ }^{2}$, Pedro Henrique Watanabe ${ }^{2}$, Urbano dos Santos Ruiz², Jane Maria Bertocco Ezequiel², Alessandro Borges Amorim², Everton Daniel², Guido Carlos Iselda Masson²}

\footnotetext{
${ }^{1}$ Financial support provided by the Fundação de Amparo à Pesquisa do Estado de São Paulo - FAPESP, São Paulo, Brazil.

2 Departamento de Zootecnia, Faculdade de Ciências Agrárias e Veterinárias/ Unesp, Universidade Estadual de São Paulo, Jaboticabal, São Paulo, Brazil, 14884-900.
}

ABSTRACT - This experiment was carried out to evaluate the effects of purified cellulose, soybean hulls and citrus pulp in the diet of weaned piglets. A total of 72 piglets (36 castrated males and 36 females) weaned at 21 days of age (BW $6.45 \pm 0.66 \mathrm{~kg}$ ) was distributed according to a randomized block design, for evaluation of performance, transit time, diarrhea incidence and blood parameters of piglets which received diets containing different sources of fiber. The experimental diets were: control diet - diet composed of corn, soybean meal and a source of lactose; control $+1.5 \%$ purified cellulose; control $+3 \%$ soybean hull and control $+9 \%$ citrus pulp. The inclusion of purified cellulose, soybean hulls and citrus pulp in diets of weaned piglets did not affect the performance or transit time of diets in the gastrointestinal tract. However, the use of purified cellulose reduced incidence of diarrhea. The use of purified cellulose, soybean hull and citrus pulp in the diet of weaned piglets does not affect performance or gastrointestinal transit time. The addition of purified cellulose promotes a beneficial effect to control the diarrhea in weaned piglets.

Key Words: dietary fiber, gut microbiota, intestinal health, weaning

\section{Introduction}

Weaning is a critical moment in swine production, gathering several factors that can affect the development of animals. Weaned piglets still have their immune and digestive systems in development, insufficient production of specific enzymes for digestion of plant ingredients and high demand for nutrients (Aumaitre, 2000; Hedemann et al., 2006).

The weaning stress causes physiological and metabolic responses, which may alter blood parameters. Some nutrients and substances present in some ingredients may affect these responses or stimulate inflammatory response due to the presence of anti-nutritional or allergenical factors. However, other elements may have prebiotic function and improve the health status of piglets (Thomaz, et al., 2009).

In this context, the maintenance of intestinal health is an important factor to minimize or prevent poor performance, morbidity and mortality of piglets. Thus, the dietary ingredients should be selected to prevent disturbances in the digestive tract (Montagne et al., 2003; Budiño et al., 2010).

Feed ingredients generally used to promote intestinal health in piglets, such as milk derivatives and other ingredients of animal origin are expensive, and the use of antibiotics as growth promoters has been restricted in animal production. Therefore, it is important to search for new technologies or feed ingredients which can contribute to efficient activity of the gastrointestinal tract (GIT) of animals, improving their good performance.

Certain types of dietary fibers may be used to promote intestinal health. Despite the anti-nutritive properties of some fractions of non-starch polysaccharides in animal metabolism, we can observe some benefits for weaned piglets, such as stimulus to gut development (Longland et al., 1994).

Thus, several strategies have been implemented for the use of soluble or insoluble fibers from certain ingredients, in an attempt to manage the gut microbiota and reduce its colonization by pathogens. There is evidence that increase in the dietary content of non-starch polysaccharides may increase the number of beneficial microbiota in the small intestine, due to the fermentation of carbohydrates instead of proteins (Molist et al., 2009).

Based on the composition of dietary fiber of ingredients and their effects on health and welfare, fibers can no longer be considered anti-nutritional factors for monogastric animals.

The objective of this study was to evaluate the effects of purified cellulose, citrus pulp and soybean hull as sources of fiber on the performance, transit time, incidence of diarrhea, and blood parameters of newly weaned piglets. 


\section{Material and Methods}

The experiment was carried out in the Setor de Suinocultura do Departamento de Zootecnia da Faculdade de Ciências Agrárias e Veterinárias/Unesp, Campus de Jaboticabal, São Paulo, Brazil. The experimental protocols used in this study had been approved by the Ethics Committee for Use of Animals of the Universidade Estadual Paulista, Jaboticabal, São Paulo, Brazil.

A total of 72 piglets (initial weight $6.45 \pm 0.66 \mathrm{~kg}$ ) from Topigs genetic line ( 36 castrated males and 36 females) were weaned at 21 days of age. Animals were randomly allotted to $2.55-\mathrm{m}^{2}$ pens equipped with drinkers and semi-automatic feeders with four treatments and nine replicates. During the first 20 days of the experimental period, piglets were kept in wooden pens equipped with $100-\mathrm{W}$ lamps, providing extra heat. A randomized blocks experimental design was used to control differences at initial weight and the experimental unit was composed of one castrated male and one female.

The experimental diets were: control diet-diet composed of corn, soybean meal and a source of lactose; control + $1.5 \%$ purified cellulose; control $+3 \%$ soybean hulls and control $+9 \%$ citrus pulp. It had been previously established that diets containing fiber sources would have the same amounts of crude fiber.

Corn, soybean meal, purified celulose, soybean hulls, citrus pulp (Table 1) and experimental diets (Table 2) were analyzed at the Laboratório de Nutrição Animal e Laboratório de Ingredientes e Gases Poluentes da Faculdade de Ciências Agrárias e Veterinárias/Unesp, Campus de Jaboticabal. Ingredients and diets were analyzed for dry matter (DM), crude protein $(\mathrm{CP})$, ether extract (EE), mineral matter (MM) and organic matter $(\mathrm{OM})$ content according to Silva \& Queiroz (2002). Gross energy (GE) of ingredients and diets was determined by calorimetry (Parr American, model 6400, Parr Instrument Company, Ilinois, USA). Total starch was determined following the method of extraction of Hendrix (1993) and for the colorimetric reading acid, the dinitrosalicylic acid (Miller, 1959) was used. Total dietary fiber (TDF), insoluble fiber (IF) and soluble fiber (SF) were analyzed according to AOAC (1995). Analyses of neutral detergent fiber (NDF), acid detergent fiber (ADF) and the determination of hemicellulose content were performed as described by Van Soest et al. (1991).

Experimental diets were formulated according to Rostagno et al. (2005) in order to meet the nutritional requirements for piglets. No antibiotics or any other growth promoters were added to the diets (Table 2).

Animals and leftovers were weighed at the beginning and at the end of each phase, in order to obtain the average daily gain (ADG), average daily feed intake (ADFI), and feed conversion (FC). Performance results were analyzed in the following periods: 1 - from 21 to 35 days, 2 - from 21 to 50 days and 3 - from 21 to 63 days of age.

To verify the influence of the experimental diets on diarrhea incidence, an assessment of the fecal scores of piglets was carried out during the first 21 days of the experimental period. Fecal consistency was verified twice a day, at 08:00 $\mathrm{h}$ and 17:00 h, by means of visual analysis, according to the following scores: 1 - normal feces, 2 - soft feces and 3 - watery feces. Feces scoring 1 and 2 were considered non-diarrheic and feces scoring 3 were considered diarrheic. The same observer performed this assessment at all times.

The transit time of the diets was determined during the performance assay, from 50 to 60 days of age. Piglets were fed $200 \mathrm{~g}$ of diet with $2 \%$ ferric oxide as marker and considered as the beginning of assesment. The transit time was

Table 1 - Chemical and energetic composition of ingredients used in the formulation of experimental diets (as is basis)

\begin{tabular}{|c|c|c|c|c|c|}
\hline Nutrients and energy ${ }^{1}$ & Corn & Soybean meal & Purified cellulose & Soybean hulls & Citrus pulp \\
\hline $\mathrm{DM}, \%$ & 88.72 & 90.28 & 96.55 & 90.31 & 88.90 \\
\hline OM, \% & 87.59 & 84.57 & 96.17 & 87.26 & 84.20 \\
\hline $\mathrm{CP}, \%$ & 9.16 & 47.98 & 0.29 & 11.05 & 8.21 \\
\hline Starch, \% & 64.08 & 10.51 & - & 5.56 & 4.12 \\
\hline $\mathrm{CF}, \%$ & 2.31 & 6.71 & 88.55 & 43.66 & 15.47 \\
\hline NDF, $\%$ & 10.58 & 14.15 & 95.32 & 66.01 & 21.34 \\
\hline TDF, \% & 17.19 & 38.41 & 93.73 & 76.37 & 42.36 \\
\hline IF, \% & 16.01 & 35.45 & 93.09 & 70.69 & 11.73 \\
\hline $\mathrm{SF}, \%$ & 1.19 & 2.95 & 0.64 & 5.66 & 30.63 \\
\hline Pectin, \% & 12.84 & 12.59 & - & 10.25 & 24.69 \\
\hline $\mathrm{ME}, \mathrm{kcal} / \mathrm{kg}$ & $3340^{2}$ & $3253^{2}$ & 487 & 1882 & 2578 \\
\hline
\end{tabular}

${ }^{1}$ Nutrient values and energy determined at present study.

2 Metabolizable energy value described by Rostagno et al. (2005).

DM - dry matter; OM - organic matter; CP - crude protein; EE - ether extract; CF - crude fiber; NDF - neutral detergent fiber; ADF - acid detergent fiber; TDF - total dietary fiber; IF - insoluble fiber; SF - soluble fiber; ME - metabolizable energy. 
Table 2 - Centesimal, chemical and energetic compositions of experimental diets

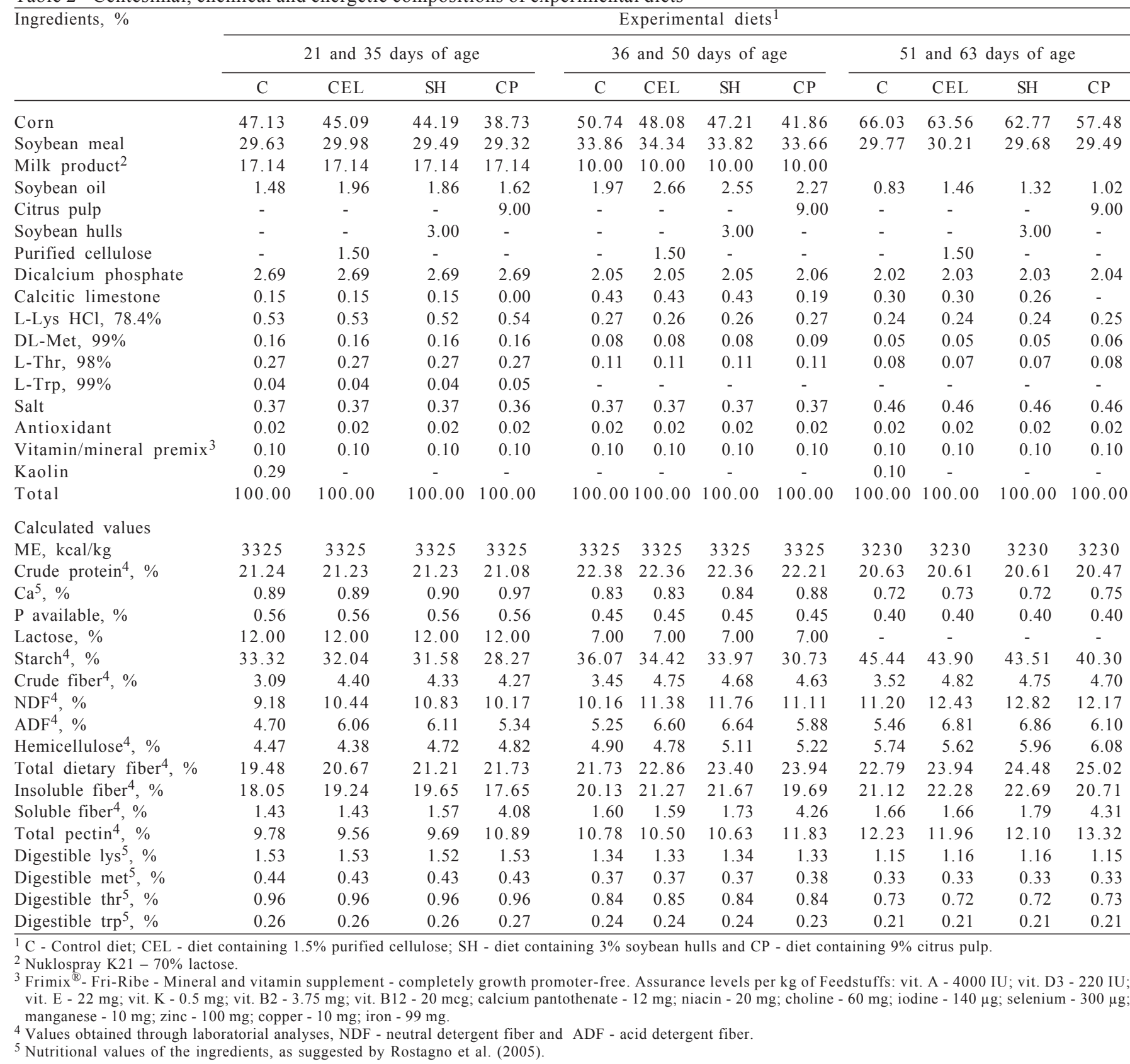

determined when the first feces with ferric oxide color appeared. When there were no leftovers, the animals would be offered more feedstuff without the marker and ad libitum.

Blood samples were collected from the jugular vein of one piglet from each experimental unit, at 21,35 and 50 days of age.

The complete blood count yielded the concentration of red blood cells $-\mathrm{He}\left(\mathrm{mm}^{3} \times 10^{3}\right)$, hemoglobins $-\mathrm{Hb}(\mathrm{g} \%)$, hematocrit- $\mathrm{Ht}(\%)$ and leukocytes $-\mathrm{Le}\left(\mathrm{mm}^{3}\right)$. A differential leukocyte count was also carried out to calculate the percentage of the following: eosinophils - EOS, band neutrophils (immature) - NBas, segmented neutrophils (mature) - NSeg, lymphocytes - LINF and monocytes MON.

Blood samples were centrifuged and the serum obtained was utilized for analysis of serum total proteins and electrophoresis of protein fractions. The concentration of serum total protein was determined by the biuret method, and its reading was performed by spectrophotometry. Polyacrylamide gel electrophoresis containing sodium dodecyl sulfate (SDS-PAGE) was used for the fractionation of serum proteins, according to Weber \& Osborn (1969). Protein fractions were read by a videodensitometer. Proteins were identified by comparing their electrophoretic mobilities with marker, with molecular weights (MW) of 28.000 daltons 
(D), 45.000 D, 66.000 D, 97.400 D, 116.000 D and 205.000 D. From the methodology used, albumin (MW $=69.000 \mathrm{D})$, immunoglobulin $\mathrm{A}(\mathrm{MW}=139.000 \mathrm{D})$ and $\mathrm{G}$, heavy and light chains ( $\mathrm{MW}=32.000$ and $18.000 \mathrm{D}$, respectively) were determined. The globulin value was obtained by calculating the difference between total protein and serum albumin values. The albumin/globulin $(\mathrm{A} / \mathrm{G})$ ratio was calculated once the serum albumin and globulin results were obtained.

Data observed in both experiments were submitted to variance analysis through the GLM procedure (General Linear Models) using the SAS ${ }^{\circledR}$ program (Statistical Analysis System, version 8.0) and means were compared by the Tukey test (5\%). The normality of the errors was tested by the Cramer-von Misses Test, according to Everitt (1998). Non-parametric statistics were used to evaluate the diarrhea incidence, and means were compared by the KruskallWallis Test (5\%). Blood parameters data were analyzed in a split plot designs. In these designs, the experimental diets were used as whole plots (control; control $+1.5 \%$ purified cellulose; control $+3 \%$ soybean hull and control $+9 \%$ citrus pulp), and the ages at which the samples were collected were used as subplots.

\section{Results and Discussion}

No differences $(\mathrm{P}>0.05)$ were verified in the performance variables (Table 3 ), for any of the studied periods.

There is a certain disparity between the results in relation to the performance of piglets fed diets containing fiber sources, and this could be explained by the chemical and physical characteristics of each source and its degree of lignification, in addition to the amount included in the diet (Wenk, 2001). Although Mateos et al. (2006) have recommended that the diets of piglets weighing between 6 and $12 \mathrm{~kg}$ contain $60 \mathrm{~g}$ NDF per $\mathrm{kg}$, it was observed in the present study that diets with about $110 \mathrm{~g}$ NDF per kg did not reduce the performance of piglets.

Results observed in the daily intake and feed conversion were similar to those obtained by Schiavon et al. (2004), who used $12 \%$ beet pulp in the diet of weaned piglets and did not observe any influence on these two variables. However, they verified a poorer weight gain in animals fed the diet containing beet pulp as fiber source.

Högberg \& Lindberg (2004) observed increase in the weight gain of weaned piglets, when they received a higher quantity of fibers in their diets, but the authors reported that such increase in weight is associated with increase in the weight of internal organs. Molist et al. (2009) evaluated feedstuffs for weaned piglets containing wheat bran, beet pulp, a combination of both or without a fiber source, and they observed that during the first 10 days after weaning, animals which received the diet containing wheat bran had a higher feed intake, when compared with those that consumed the diet which did not contain a fiber source. However, the authors did not observe differences in weight gain or feed conversion.

Although Stagonias \& Pearce (1985) and Drochner et al. (2004) reported that transit time is influenced by the level of fiber in the diet, the transit time of diets in the gastrointestinal tract (Table 3 ) was not influenced $(\mathrm{P}>0.05)$ by the inclusion of different fiber sources. An increase in the gastrointestinal transit time may be associated with the type of fiber present in the diet, in addition to other physical characteristics of the feed, such as particle size, amount of fiber ingested and animal weight (Castro Júnior et al., 2005). Drochner et al. (2004) reported that increase in transit time is more associated

Table 3 - Average daily feed intake (ADFI), average daily gain(ADG), feed conversion (FC) and intestinal transit time of diets for weaned piglets, fed different dietary fiber sources

\begin{tabular}{|c|c|c|c|c|c|c|}
\hline \multirow[b]{2}{*}{ Age, days } & \multicolumn{4}{|c|}{ Experimental diets } & \multirow[t]{2}{*}{ CV (\%) } & \multirow[t]{2}{*}{$\mathrm{P}$} \\
\hline & $\mathrm{C}$ & CEL & $\mathrm{SH}$ & $\mathrm{CP}$ & & \\
\hline \multicolumn{7}{|l|}{$21-35$} \\
\hline ADG, $\mathrm{g}$ & 202.50 & 230.00 & 225.83 & 215.27 & 23.37 & 0.6722 \\
\hline $\mathrm{FC}$ & 1.81 & 1.59 & 1.59 & 1.62 & 20.59 & 0.4515 \\
\hline \multicolumn{7}{|l|}{$21-50$} \\
\hline $\mathrm{FC}$ & 1.61 & 1.57 & 1.62 & 1.68 & 7.53 & 0.2916 \\
\hline \multicolumn{7}{|l|}{$21-63$} \\
\hline ADFI, $g$ & 703.31 & 759.38 & 738.73 & 728.77 & 14.52 & 0.9318 \\
\hline ADG, $\mathrm{g}$ & 424.70 & 470.83 & 431.87 & 416.88 & 13.19 & 0.2435 \\
\hline $\mathrm{FC}$ & 1.68 & 1.62 & 1.71 & 1.74 & 6.21 & 0.5513 \\
\hline TTGI, min. & 582.14 & 584.07 & 571.00 & 598.07 & 12.51 & 0.8896 \\
\hline
\end{tabular}

C - control diet; CEL - diet containing 1.5\% purified cellulose; SH - diet containing 3\% soybean hulls; CP - diet containing 9\% citrus pulp; CV - coefficient of variation; TTGI - gastrointestinal transit time. 
with the amount of soluble fiber (pectin) in the food, because this fraction may reduce the $\mathrm{pH}$ of the stomach and, consequently, retard the arrival of the digesta in the duodenum, as well as enhance viscosity, thus contributing to increasing in transit time of diets in the gastrointestinal tract.

Freire et al. (2000) used different fiber sources (wheat bran, beet pulp, soybean hulls, alfafa meal) in the diet of weaned piglets and observed reduction in the transit time when animals received alfafa meal in their diet. Those authors concluded that this result is due to a higher amount of insoluble fibers that is present in this ingredient.

A higher occurrence of diarrhea $(\mathrm{P}<0.01)$ was observed in animals fed on diets containing soybean hulls and citrus pulp (Table 4), followed by those that received the control $\operatorname{diet}(\mathrm{P}<0.01)$. A lower incidence of diarrhea $(\mathrm{P}<0.01)$ was observed in piglets that consumed the diet containing purified cellulose.
The inclusion of purified cellulose may have blocked adherence sites of certain pathogenic bacteria, thus immobilizing or reducing their ability to remain in the gastrointestinal tract and, consequently, resulting in their elimination with the chyme and reducing diarrhea (Schley \& Field, 2002; Yin et al., 2004).

The incidence of diarrhea in animals fed diets with soybean hulls or citrus pulp may be explained by higher levels of soluble fiber and their effects as substrate for pathogenic bacteria. The use of soluble fiber (Guar gum) in diets for piglets caused a higher incidence of diarrhea, with a positive correlation between the presence of this fiber fraction and diarrhea (Pluske et al., 1998).

It was verified that the inclusion of fiber sources in diets of piglets influenced $(\mathrm{P}<0.05)$ the concentration of red blood cells and hemoglobin (Table 5). Red blood cell, hematocrit, band neutrophil, segmented neutrophil, lymphocyte and monocyte values were within the range

Table 4 - Fecal scores and diarrhea incidence in weaned piglets fed different sources of dietary fiber

\begin{tabular}{|c|c|c|c|c|c|c|}
\hline \multirow[t]{2}{*}{ Scoring $^{1}$} & \multicolumn{4}{|c|}{ Experimental diets } & \multirow[t]{2}{*}{ Total } & \multirow[t]{2}{*}{$\%$ Scoring } \\
\hline & C & CEL & SH & $\mathrm{CP}$ & & \\
\hline 1 & 30 & 51 & 34 & 28 & 143 & 19,86 \\
\hline 2 & 125 & 109 & 101 & 112 & 447 & 62,08 \\
\hline 3 & 25 & 20 & 45 & 40 & 130 & 18,06 \\
\hline TOTAL & 180 & 180 & 180 & 180 & 720 & 100 \\
\hline$\%$ score $3^{*}$ & $13.89 \mathrm{~b}$ & $11.11 \mathrm{c}$ & $25.00 \mathrm{a}$ & $22.22 \mathrm{a}$ & - & - \\
\hline
\end{tabular}

${ }^{1}$ Scoring: 1 - normal feces; 2 - soft stools and 3 - watery stools.

${ }^{2} \mathrm{C}$ - control diet; CEL - diet containing $1.5 \%$ purified cellulose, SH - diet containing 3\% soybean hulls and CP - diet containing $9 \%$ citrus pulp.

Means followed by same letter in row did not differ $(\mathrm{P}>0.01)$ by Kruskal-Wallis test.

* Percentage of diarrhea cases.

Table 5 - Blood parameters in piglets, according to different dietary fiber sources and age at blood sampling

\begin{tabular}{|c|c|c|c|c|c|c|c|c|c|c|c|}
\hline \multirow[t]{2}{*}{ Variable $^{1}$} & \multicolumn{4}{|c|}{ Experimental diets (D) } & \multicolumn{3}{|c|}{ Age at the time of blood sampling (A) } & \multirow[t]{2}{*}{$\mathrm{CV}(\%)$} & \multicolumn{3}{|c|}{ Effects } \\
\hline & $\mathrm{C}$ & CEL & $\mathrm{SH}$ & $\mathrm{CP}$ & 21 & 35 & 50 & & $\mathrm{D}$ & A & $\mathrm{D} \times \mathrm{A}$ \\
\hline $\mathrm{He}, \mu \mathrm{L}$ & $6.00 \mathrm{a}$ & $5.68 \mathrm{~b}$ & $5.75 \mathrm{ab}$ & $5.90 \mathrm{ab}$ & $6.24 \mathrm{a}$ & $6.27 \mathrm{a}$ & $5.25 \mathrm{~b}$ & 8.09 & * & $* *$ & NS \\
\hline $\mathrm{Hb}, \mathrm{g} / \mathrm{dL}$ & $12.28 \mathrm{a}$ & $11.65 b$ & $11.99 \mathrm{ab}$ & $12.27 \mathrm{a}$ & $12.78 \mathrm{a}$ & $12.40 \mathrm{ab}$ & $1.15 \mathrm{c}$ & 7.70 & $*$ & $* *$ & NS \\
\hline $\mathrm{Ht}, \%$ & 37.11 & 35.87 & 36.42 & 36.86 & $38.80 \mathrm{a}$ & $37.19 \mathrm{~b}$ & $34.44 \mathrm{c}$ & 5.78 & NS & $* *$ & NS \\
\hline EOS, \% & 0.76 & 0.92 & 0.82 & 0.79 & 0.77 & 0.72 & 0.97 & 56.01 & NS & NS & NS \\
\hline LINF，\% & 60.50 & 58.03 & 57.78 & 59.75 & $61.22 \mathrm{ab}$ & $46.06 \mathrm{c}$ & $58.44 \mathrm{~b}$ & 21.50 & NS & $* *$ & NS \\
\hline MON, \% & 0.69 & 0.80 & 0.77 & 0.76 & $0.60 \mathrm{~b}$ & $0.79 \mathrm{~b}$ & $0.85 \mathrm{a}$ & 52.58 & NS & $*$ & NS \\
\hline Total protein, $\mathrm{g} / \mathrm{dL}$ & 5.51 & 5.67 & 5.41 & 5.48 & $5.34 \mathrm{~b}$ & $5.36 \mathrm{~b}$ & $5.88 \mathrm{a}$ & 9.92 & NS & $* *$ & NS \\
\hline Albumin, $g / d L$ & 3.77 & 3.75 & 3.78 & 3.87 & 3.70 & 3.83 & 3.85 & 11.92 & NS & NS & NS \\
\hline Globulin, g/dL & 1.74 & 1.93 & 1.63 & 1.61 & 1.65 & 1.53 & 2.01 & 22.69 & $*$ & $* *$ & $* *$ \\
\hline $\mathrm{A} / \mathrm{G}$ ratio & 2.27 & 2.19 & 2.41 & 2.50 & 2.31 & 2.60 & 2.11 & 20.42 & NS & $* *$ & $* *$ \\
\hline
\end{tabular}

${ }^{1} \mathrm{He}$ - red blood cell; Le - leukocyte; Hb - hemoglobin; Ht - hematocrit; EOS - eosinophil; NBast - band neutrophils; NSeg - segmented neutrophils; LINF - lymphocyte; MON - monocyte; albumin/globulin relation $(\mathrm{A} / \mathrm{G})$; IgA - immunoglobulin A; IgG - immunoglobulin G.

$2 \mathrm{C}$ - control diet; CEL - diet containing $1.5 \%$ purified cellulose; SH - diet containing 3\% soybean hulls and CP - diet containing $9 \%$ citrus pulp.

${ }^{3}$ Coefficients of variation. Means followed by an identical letter in the row are not differentiated from each other by Tukey test (P $\left.>0.05\right)$.

Data of EOS, Nbas and MON variables have been transformed by the equation $(\mathrm{Y}+1)^{1 / 2} ; \mathrm{NS}-\operatorname{not}$ significant $(\mathrm{P}>0.05) ; *(\mathrm{P}<0.05) ; * *(\mathrm{P}<0.01)$ 
found in reference tables (Kaneko, 1989; Bacila, 2003), and differences in values observed at collection dates were considered normal due to the development stage of the animal (Feldman, 2000).

The age of animals had an influence on red blood cells, leukocytes, hemoglobin, hematocrit, band neutrophils, segmented neutrophils and monocytes. The results observed in leukocytes were within the normal range (Kaneko, 1989; Bacila, 2003) at 21 and 50 days of age. However, these values were increased at 35 days of age, which could represent a response to post-weaning diarrhea, seeing that an increase in this white blood cell count may mean a possible response to bacterial infections (Swenson, 1984).

Fiber sources did not affect $(\mathrm{P}>0.05)$ the concentrations of total protein and albumin (Table 5), but they influenced $(\mathrm{P}<0.05)$ the concentrations of immunoglobulin $\mathrm{A}$, whose smallest values were observed in piglets consuming purified cellulose. This can be explained by the lower incidence of diarrhea, considering that the production of immunoglobulin A is stimulated by enteric infections of the gut mucosa (Silva et al., 2008).

Age at collection did not influence $(\mathrm{P}>0.05)$ the concentrations of albumin and IgA (Table 5), but they influenced $(\mathrm{P}<0.05)$ the concentration of total protein, with its highest value $(\mathrm{P}<0.05)$ observed at 50 days of age. Interactions were observed $(\mathrm{P}<0.05)$ for globulin and immunoglobulin G concentrations, as well as for the albumin/ globulin relation (Table 6).

It was verified that animals at 50 days of age receiving the diet containing purified cellulose presented the highest globulin concentrations $(\mathrm{P}<0.05)$, in comparison with those fed diets containing soybean hull and citrus pulp. At 50 days of age, piglets which received diet with purified cellulose presented the highest concentrations of this blood protein $(\mathrm{P}<0.05)$, in comparison with the concentrations found at 21 and 35 days of age.

At 50 days of age, the highest albumin/globulin ratio was also observed in animals which ingested the diet containing citrus pulp, in relation to those that received purified cellulose $(\mathrm{P}<0.05)$. For piglets which fed diet containing purified cellulose, the lowest values were found at 50 days of age, when compared with those observed at 21 and 35 days of age $(\mathrm{P}<0.05)$. Modifications in the albumin/ globulin relation indicate infections, because a higher quantity of globulin is a sign that the organism is mobilizing its immunogloblulins in order to fight against possible infections (Bacila, 2003).

It was observed that the inclusion of purified cellulose in diet of piglets at 50 days of age increased the concentration of immunoglobulin $\mathrm{G}(\mathrm{P}<0.05)$, in comparison with piglets fed diets containing soybean hulls and citrus pulp. Piglets which received the diet containing citrus pulp presented higher immunoglobulin $\mathrm{G}$ concentrations $(\mathrm{P}<0.05)$ at 21 days of age, when compared with 35 and 50 days of age. Silva et al. (2008) described that the concentration of immunoglobulin $\mathrm{G}$ is increased in acute infections because they act directly against bacterial antigens (Silva et al., 2008).

The action mechanisms of fiber sources included in diets are not yet clear. However, it is known that nondigested fibers may serve as substrate for beneficial bacteria, altering the gut microbiota and increasing the proportion of lactic bacteria (Schley \& Field, 2002).

Table 6 - Age $\times$ diet of piglets, for globulin, albumin/globulin relation (A/G) and immunoglobulin G (IgG)

\begin{tabular}{|c|c|c|c|c|c|}
\hline \multirow[t]{2}{*}{ Serum protein } & \multirow[t]{2}{*}{ Age at blood sampling } & \multicolumn{4}{|c|}{ Experimental diets } \\
\hline & & $\mathrm{C}$ & CEL & SH & $\mathrm{CP}$ \\
\hline \multirow[t]{2}{*}{ Globulin, g/dL } & 21 & 1.71 & $1.54 \mathrm{~b}$ & 1.52 & 1.80 \\
\hline & 50 & $1.97 \mathrm{AB}$ & $2.58 \mathrm{Aa}$ & $1.92 \mathrm{~B}$ & $1.57 \mathrm{~B}$ \\
\hline \multirow[t]{2}{*}{$\mathrm{A} / \mathrm{G}$} & 21 & 2.23 & $2.60 \mathrm{a}$ & 2.35 & 2.08 \\
\hline & 35 & 2.54 & $2.36 \mathrm{a}$ & 2.70 & 2.82 \\
\hline \multirow{2}{*}{$\mathrm{IgG}, \mathrm{g} / \mathrm{dL}$} & 35 & 0.62 & 0.71 & 0.62 & $0.65 \mathrm{~b}$ \\
\hline & 50 & $0.70 \mathrm{AB}$ & $1.15 \mathrm{~A}$ & $0.63 \mathrm{~B}$ & $0.50 \mathrm{Bb}$ \\
\hline
\end{tabular}

C - control diet; CEL - diet containing 1.5\% purified cellulose; SH - diet containing 3\% soybean hulls and CP - diet containing $9 \%$ citrus pulp.

Means followed by the same upper case letter in the row and lower case letter in the column are not different $(\mathrm{P}>0.05)$ by Tukey test. 


\section{Conclusions}

The use of purified cellulose, soybean hulls and citrus pulp as fiber sources in diets for weanling pigs does not affect performance or transit time of diets in the gastrointestinal tract. However, the inclusion of purified cellulose promotes beneficial effect in controlling diarrhea and improves some immunological parameters.

\section{References}

ASSOCIATION OF OFFICIAL ANALYTICAL CHEMISTRYAOAC. Official methods of analysis. 16.ed. Arlington: AOAC International, 1995. 1025p.

AUMAITRE, L.A. Adaptation and efficiency of the digestive process in the gut of the young piglet: consequences for the formulation of a weaning diet. Asian Australasian Journal of Animal Science, v.13, p.227-242, 2000. (Special issue, swine nutrition session).

BACILA, M. Bioquímica Veterinária. São Paulo: Robe, 2003. $583 \mathrm{p}$

BUDIÑO, F.E.L.; CASTRO JÚNIOR, F.G.; OTSUK, I.P. Adição de frutoligossacarídeo em dietas para leitões desmamados: desempenho, incidência de diarréia e metabolismo. Revista Brasileira de Zootecnia, v.39, p.2187-2193, 2010.

CASTRO JÚNIOR, F.G.; CAMARGO, J.C.M.; CASTRO, A.M.M.G. et al. Fibra na alimentação de suínos. Boletim da Indústria Animal, v.62, n.3, p.265-280, 2005.

DROCHNER, W.; KERLER, A.; ZACHARIAS, B. Pectin in pig nutrition, a comparative review. Journal Animal Physiology and Animal Nutrition, v.88, p.367-380, 2004.

EVERITT, B.S. The Cambridge Dictionary of Statistics. Cambridge: Cambridge University Press, 1998. 360p.

FELDMAN, B.F. Shalm's veterinary hematology. 5.ed. Philadelphia, 2000. 298p.

FREIRE, J.P.B.; GUERREIRO, A.J.G.; CUNHA, L.F. et al. Effect of dietary fiber source on total tract digestibility, caecum volatile fatty acids and digestive transit time in the weaned piglet. Animal Feed Science and Technology, v.87, p.71-83, 2000.

HEDEMANN, M.S.; ESKILDSEN, M.; LAERKE, H.N. et al. Intestinal morphology and enzymatic activity in newly weaned pigs fed contrasting fiber concentrations and fiber properties. Journal of Animal Science, v.84, p.1375-1386, 2006.

HENDRIX, D.L. Rapid extraction and analysis of nonstructural carbohydrates in plant tissues. Crop Science, v.33, n.6, p.13061311,1993

HÖGBERG, A.; LINDBERG, J.E. Influence of cereal non-starch polysaccharides and enzyme supplementation on digestion site and gut environment in weaned piglets. Animal Feed Science and Technology, v.116, p.113-128, 2004.

KANEKO, J.J. Clinical biochemistry of domestic animals. 4.ed. California: Academic Press, 1989. 932p.

LONGLAND, A.C.; CARRUTHERS, J.; LOW, A.G. The ability of piglets 4 to 8 weeks old to digest and perform on diets containing two contrasting sources of non-starch polysaccharide. Animal Production, v.58, p.405-410, 1994
MATEOS, G.G.; MARTIN, F.; LATORRE, M.A. et al. Inclusion of oat hulls in diets for young pigs based on cooked maize or cooked rice. Animal Science, v.82, p.57-63, 2006.

MILLER, G.L. Use of dinitrosalicylic acid reagent for determination of reducing sugar. Analytical Chemistry, v.31, p.426-428, 1959

MOLIST, F.; GOMES DE SEGURA, A.; GASA, A. et al. Effects of the insoluble and soluble dietary fibre on the physicochemical properties of digesta and microbial activity in early weaned piglets. Animal Feed Science and Techonology, v.149, p.346-353, 2009

MONTAGNE, L.; PLUSKE, J.R.; HAMPSON, D.J. A review of interactions between dietary fibre and the intestinal mucosa, and their consequences on digestive health in young nonruminant animals. Animal Feed Science and Technology, v. 108, p. $95-117,2003$

PLUSKE, J.R.; DURMIC, Z.; PETHICK, D.W. et al. Confirmation of the role old rapidly fermentable carbohydrates in the expression of swine dysentery in pigs after experimental infection. Journal of Nutrition, v.128, p.1737-1744, 1998

ROSTAGNO, H.S.; ALBINO, L.F.T.; DONZELE, J.L. et al Tabelas brasileiras para aves e suínos: composição dos alimentos e exigências nutricionais. 2.ed. Viçosa, MG: UFV, 2005. $186 \mathrm{p}$.

SCHIAVON, S.; TAGLIAPIETRA, F.; BAILONI, L. et al. Effects of sugar beet pulp on growth and health status of weaned piglets. Italian Journal of Animal Science, v.3, p.337-351, 2004.

SCHLEY, P.D.; FIELD, C.J. The immune-enhancing effects of dietary fibres and prebiotics. British Journal of Nutrition, v.87, Suppl. 2, p.221-230, 2002

SILVA, D.J.; QUEIROZ, A.C. Análise de alimentos: métodos químicos e biológicos. 2.ed. Viçosa, MG: Editora UFV, 2002. $235 \mathrm{p}$.

SILVA R.O.P.; LOPES, A.F.; FARIA, R.M.D. Eletroforese de proteínas séricas: interpretação e correção clínica. Revista Médica de Minas Gerais, v.18, n.2, p.116-122, 2008

STAGONIAS, G.; PEARCE, G.R. The digestion of fiber by pigs. 1. The effects of amount and type of fiber on apparent digestibility, nitrogen balance and rate of passage. British Journal of Nutrition, v.53, p.513-530, 1985

SWENSON, M.J. Dukes: fisiologia dos animais domésticos. 10.ed Rio de Janeiro: Guanabara, 1984. p.13-34.

THOMAZ, M.C.; HANNAS, M.J.; TUCCI, F.M. et al. Diferentes fontes protéicas em rações de leitões sobre a atividade da tripsina e parâmetros sanguíneos. Brazilian Journal Veterinary Research Animal Science, v.46, n.2, p.112-121, 2009.

VAN SOEST, P.J.; ROBERTSON, J.B.; LEWIS, B.A. Methods for dietary fiber, neutral detergent fiber, and nonstarch polysaccharides in relation to animal nutrition. Journal of Dairy Science, v.74, p.3583-3597, 1991

WEBER, K.; OSBORN, M. The reability of molecular weight determinations by dodecyl sulfate-polyacrylamide gel electrophoresis. Journal Biology Chemical, v.244, p.4406-4412, 1969.

WENK, C. The role of dietary fibre in the digestive physiology of the pig. Animal Feed Science and Technology, v.90, p. 21-33, 2001

YIN, Y.L.; DENG, Z.Y.; HUANG, H.L.; HOU, Z.P. Nutritional and health functions of carbohydrate for pigs. Journal of Animal and Feed Science, v.13, p.523-538, 2004 